\title{
Interactive comment on "Seismic Hazard of L'Aquila downtown (central Italy): new insights for 3D geological model based on high-resolution seismic reflection profile and borehole stratigraphy" by Marco Tallini et al.
}

Anonymous Referee \#1

Received and published: 16 March 2019

Dear Editor, I have completed reviewing this manuscript evaluating seismic hazard L'Aquila in Italy based on integrated geological and geophysical data which might be a state of the art approach for other historical downtowns in Italy and also other extensional regions such as Greece and western Turkey. One of the impressed points of this manuscript is showing the significance of field-based local and regional geological information to better understand seismic hazard for a very specific and fine-scale problem which is crucial for the society. The language of the paper is very good and easy to follow and it is well structured. The only thing that I would like to request from 
authors providing a photo from L'Aquila downtown to readers. I visited the town but other readers to whom may not be visited it might be very useful to keep this paper in their mind. Yours Sincerely

Interactive comment on Solid Earth Discuss., https://doi.org/10.5194/se-2019-25, 2019.

Interactive

comment 